\title{
RP-HPLC METHOD FOR SIMULTANEOUS DETERMINATION OF METRONIDAZOLE AND OFLOXACIN IN SYNTHETIC MIXTURE
}

\author{
Vania Maslarska $^{1}$, Boyka Tsvetkova $^{2}$, Lily Peikova $^{3}$, Stanislav Bozhanov $^{4}$
}

\begin{abstract}
Development and validation of a high-performance liquid chromatographic analytical procedure for simultaneously determining metronidazole and ofloxacin in a synthetic mixture is described in this paper. The separation was made with a LiChrosorb ${ }^{\circledR} \mathrm{RP}-18(250 \times 4.6 \mathrm{~mm})$ column, at $30{ }^{\circ} \mathrm{C}$ temperature, with isocratic mode and mobile phase, containing triethylamine, acetonitrile, and $0.3 \%$ o-phosphoric acid solution $(0.02: 20: 80$ $\mathrm{v} / \mathrm{v} / \mathrm{v}$ ). Eluent was monitored at $290 \mathrm{~nm}$ and the flow rate was $1.0 \mathrm{ml} / \mathrm{min}$. Metronidazole and ofloxacin were effectively separated with retention time $\left(\mathrm{t}_{\mathrm{r}}\right)$ of $3.42 \mathrm{~min}$ and $6.15 \mathrm{~min}$, respectively, within the selected chromatographic conditions. The method was validated for analytical parameters: specificity, linearity, precision, accuracy, and limits of detection and quantitation. The calibration curves were linear in the concentration range of 12.5 to $100.0 \mu \mathrm{g} / \mathrm{ml}$ for metronidazole and ofloxacin, and the regression coefficients were more than 0.999 . For metronidazole and ofloxacin the recovery was $100.01 \%$ and $100.04 \%$, respectively. This analytical procedure is applicable for the quality control of drug formulations.
\end{abstract}

UDC Classification: 543.6, DOI: http://dx.doi.org/10.12955/cbup.v4.871

Keywords: metronidazole, ofloxacin, RP-HPLC, validation, drugs, quality control.

\section{Introduction}

Ofloxacin (OFL), acting as an antimicrobial agent, is a second-generation fluoroquinolone. It is also known as (RS)-9-fluoro-3-methyl-10-(4-methylpiperazin-1-yl)-7-oxo-2,3-dihydro-7H-pyrido[1,2,3de]-1,4-benzoxazine-6-carboxylic acid.

This antimicrobial agent, Ofloxacin, is characterized by an expansive pharmacokinetic profile. This agent is used in the treatment of urinary tract, prostate, skin, and respiratory tract infections (Fairclough \& Silk, 2005). It is also used to treat certain sexually transmitted diseases. It is more active than Ciprofloxacin against Chlamydia trachomatis, it is also active against Mycobacterium leprae (Monk \& Campoli-Richards, 1987). It is endorsed in the British pharmacopeia (BP; British pharmacopeia, 2007), United State Pharmacopoeia (USP; United State Pharmacopoeia, 2005), and the European Pharmacopoeia (EuPh; European Pharmacopoeia, 2005). According to literature surveys, there are various analytical methods for estimating OFL alone and in combination, such as by spectrophotometric and atomic absorption spectroscopy (Shivkumar, Gunturu, \& Indrakanti 2011; Rege, Sathe, Salvi, \& Shotri, 2011; Bhusari \& Chaple, 2009; Abdulgader, Ebraheem, \& Elbashir, 2012; Vinay, Revanasiddappa, Divya, \& Rajendraprasad, 2009; Hesham 2005), potentiometric and conductometric (Tuncel \& Atkosar 1992), high performance liquid chromatography (High Performance Liquide Chromatography; Attimarad 2010; Miniyar et al., 2012; Shinde, Bhoir, Pawar, Yadav, \& Bhagwat, 2010; Khandagle, Gandhi, Deshpande, \& Gaikwad, 2011; Kotaiah, Shaikh, Rao, Venkateswarlu, \& Konda, 2011; Narayana, Manohara, \& Appala, 2006), and liquid chromatography tandem-mass spectrometry Leea, Pearta, \& Svobodab, 2007; Tuerk et al., 2006).

The chemical structure of metronidazole (MET) is 2-(2-Methyl-5-nitro-1H-imidazol-1-yl) ethanol. It is an antiprotozoal, antiamebic, and antibacterial drug (Block \& Beale, 2004). Ofloxacin has a reduced activity against anaerobic pathogens. Therefore, a combination of OFL with an antimicrobial agent against anaerobes, such as MET, appears of interest for the treatment of mixed aerobic and anaerobic infections. The official assay method in BP (British pharmacopeia, 2007), is non-aqueous titration. For the estimation of MET alone and in combination, various analytical methods have been reported, such

\footnotetext{
${ }^{1}$ Vania Maslarska, Medical University of Sofia, Faculty of Pharmacy, Department of Chemistry, 2 Dunav St., 1000 Sofia, Bulgaria, vmaslarska@mail.bg

${ }^{2}$ Boyka Tsvetkova, Medical University of Sofia, Faculty of Pharmacy, Department of Pharmaceutical Chemistry, 2 Dunav St., 1000 Sofia, Bulgaria

${ }^{3}$ Lily Peikova, Medical University of Sofia, Faculty of Pharmacy, Department of Pharmaceutical Chemistry, 2 Dunav St., 1000 Sofia, Bulgaria

${ }^{4}$ Stanislav Bozhanov, Medical University of Sofia, Faculty of Pharmacy, Department of Chemistry, 2 Dunav St., 1000 Sofia, Bulgaria
} 
as UV spectrometry (Mahrouse 2012; Mahrouse \& Elkady 2011; Natesh 2013), and HPLC (Khadabadi \& Devkar 2013; Patel, Shah, \& Patel, 2009; Ramzia, Asma, Ehab, Maha, \& Asma, 2015; Piponski et al., 2015). A few reverse phase HPLC (RP-HPLC) assay methods have been reported for the simultaneous quantitative estimation of OFL and MET in pharmaceutical dosage forms, using phosphate buffers (at various $\mathrm{pH}$ levels) and organic solvent mixtures (Kasabe, Shitole, Waghmare, \& Mohite, 2009; Bind, Lokhande, Munigela, Kolhal, \& Gupta, 2015). This research proposes a new simple and precise chromatographic method, without using buffers in preparation for the mobile phase and with improved analytical characteristics.

\section{Data and Methodology}

Reference standards for MET and OFL were obtained from Sigma Aldrich, Germany. Acetonitrile of HPLC grade was procured from Merck Ltd, Germany. Synthetic mixture, containing MET, OFL, microcrystalline cellulose (type Vivapur $101^{\circledR}$, JRS Pharma-Germany), lactose monohydrate (Meggle Pharma-Germany), cross-linked carboxymethylcelulose sodium (Vivasol ${ }^{\circledR}$, JRS Pharma-Germany), povidone (Kollidone ${ }^{\circledR} \mathrm{K} 30, \mathrm{BASF}-\mathrm{Germany}$ ), magnesium stearate, and silica colloidal anhydrous (Aerosil ${ }^{\circledR} 200$, Evonik Ind.) were used as excipients. All other chemical reagents were of analytical grade.

HPLC Analysis

The HPLC analysis was performed by isocratic elution with a flow rate $1.0 \mathrm{ml} / \mathrm{min}$. For the analysis, a HPLC system (SHIMADZU Corporation, LC-20 AD quaternary pump) was used with a Shimadzu SPD-20A ultraviolet-visible (UV/VIS) detector. LabSolutions (Shimadzu Corporation) software was used for recording the data. Separation was carried out at $30{ }^{\circ} \mathrm{C}$, using LiChrosorb ${ }^{\circledR} \mathrm{RP}-18(250 \times 4.6$ $\mathrm{mm}$ ) column, packed with octadecylsilyl silica gel 5- $\mu \mathrm{m}$. The mobile phase, containing triethylamine, acetonitrile, and 0.3\% o-phosphoric acid solution $(0.02: 20: 80 \mathrm{v} / \mathrm{v} / \mathrm{v})$ was sonicated for $10 \mathrm{~min}$ and then filtered through a $0.45-\mu \mathrm{m}$ filter paper. The analysis was performed at $290 \mathrm{~nm}$ with $20 \mu \mathrm{l}$ aliquots of the solution were injected. The chromatogram is shown in Figure 1.

Figure 1: Typical chromatogram of Metronidazole and Ofloxacin

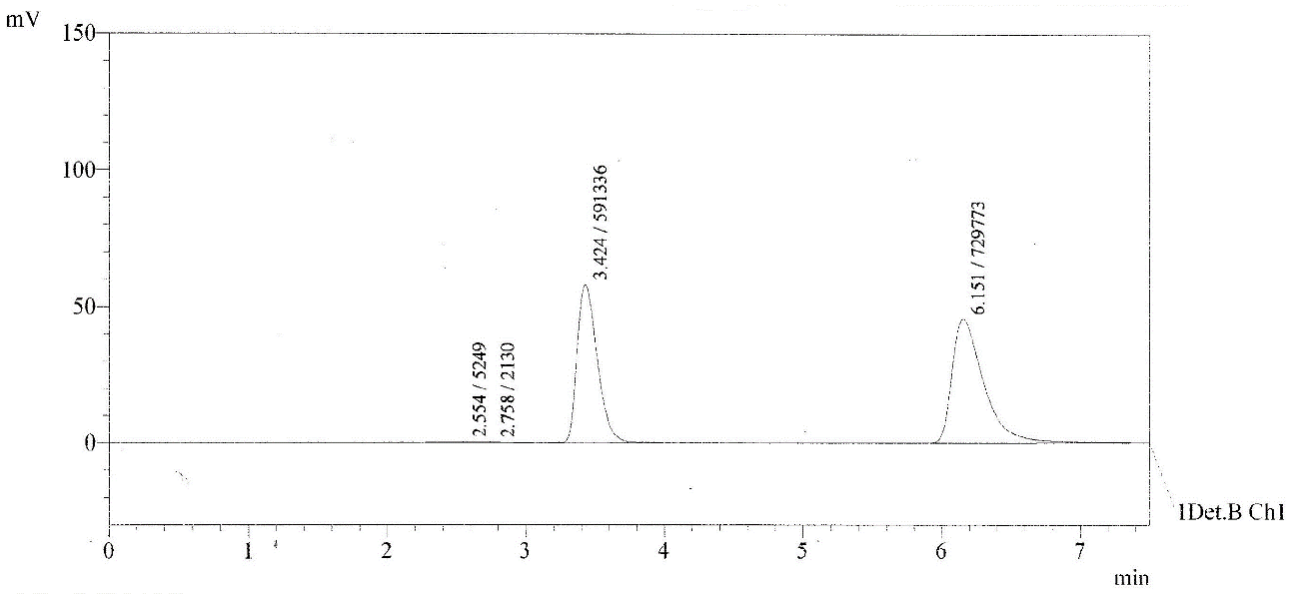

Source: Author

Accurately weighed $50 \mathrm{mg}$ of MET and $50 \mathrm{mg}$ OFL working standards were transferred into a volumetric flask $(100 \mathrm{ml})$. After adding about $70 \mathrm{ml}$ solvent A (mixture of $0.3 \%$ o-phosphoric acid solution and acetonitrile; 80:20 v/v), the mixture was sonicated for about 2 min and then made up to the volume, with the solution suitably diluted to produce a concentration of $0.05 \mathrm{mg} / \mathrm{ml}$ of MET and $0.05 \mathrm{mg} / \mathrm{ml}$ of OFL, respectively.

A bulk mixture of both drugs was prepared using $500 \mathrm{mg}$ MET, $500 \mathrm{mg}$ OFL, and excipients of $100 \mathrm{mg}$ microcrystalline cellulose (type Vivapur $101^{\circledR}$, JRS Pharma-Germany), $140 \mathrm{mg}$ lactose monohydrate (Meggle Pharma-Germany), $60 \mathrm{mg}$ cross-linked sodium carboxymethylcelulose (Vivasol $^{\circledR}$ JRS Pharma-Germany), $10 \mathrm{mg}$ povidone (Kollidone ${ }^{\circledR}$ K30, BASF-Germany), $14 \mathrm{mg}$ magnesium stearate, and $6 \mathrm{mg}$ silica colloidal anhydrous (Aerosil ${ }^{\circledR} 200$, Evonik Ind.), which were used 
in the tablet formulation and well triturated. A powder equivalent to $250 \mathrm{mg}$ of MET and $250 \mathrm{mg}$ of OFL was weighed accurately and transferred into a $50 \mathrm{ml}$ volumetric flask, with $25 \mathrm{ml}$ of solvent A added, and then sonicated for 10 minutes. The suspension was then made up to volume with solvent $\mathrm{A}$ and filtrated. The final concentrations were $50 \mu \mathrm{g} / \mathrm{ml}$ of MET and $50 \mu \mathrm{g} / \mathrm{ml}$ of OFL.

\section{Results and Discussion}

Several mobile phase combinations were trialed for optimization of the RP-HPLC conditions. Taking into account the protolysis constants $\left(\mathrm{K}_{\mathrm{a}}\right)$ and solubility of both the compounds, several important parameters, such as, percentage and type of organic modifier, $\mathrm{pH}$ of the mobile phase, and concentration of the acid, were studied. Resolution was the most important criterion for the method and it was imperative to achieve adequate separation. The trials showed that a mobile phase, consisting of triethylamine, acetonitrile, and $0.3 \%$ o-phosphoric acid solution, in the proportion of 0.02:20:80 $\mathrm{v} / \mathrm{v} / \mathrm{v}$, with reverse phase LiChrosorb ${ }^{\circledR} \mathrm{RP}-18(250 \mathrm{x} 4.6 \mathrm{~mm})$ column, yielded symmetric and sharp peaks. Greatly improved detector responses for both drugs were obtained at the optimum wavelength of $290 \mathrm{~nm}$.

As shown in Figure 1, the retention times were $3.42 \mathrm{~min}$ for MET and $6.15 \mathrm{~min}$ for OFL. The method was simple and had a shorter run time (7 min) in comparison with that reported by Patel (2011) and Bind et al. (2015). The proposed method was validated in terms of specificity, linearity, accuracy, precision, and limits of detection and quantitation, according to guidelines of the International Council on Harmonisation of Technical Requirements for Registration of Pharmaceuticals for Human Use (ICH guidelines, 2005).

\section{Method Validation}

The selectivity of the current method demonstrated adequate separation of the two active ingredients (MET and OFL). The matrix components, e.g., excipients, did not interfere with the two analytes.

For examining linearity, standard solutions containing MET (12.50-100.0 $\mu \mathrm{g} / \mathrm{ml})$ and OFL (12.50$100.0 \mu \mathrm{g} / \mathrm{ml}$ ) were prepared in the solvent A. Each concentration level was triplicated in chromatography, using $20 \mu \mathrm{l}$ injections for each standard solution.

In addition, studies were prepared with five different concentrations of mixtures for both drugs. The responses, measured as peak areas, are shown in Table 1. The calibration curves showed linearity in the selected concentration range for both drugs. The linear regression equations for MET and OFL were as follows: $\mathrm{y}=11827.3 \times-31.6$; and $\mathrm{y}=14929.5 \times-10454.4$, respectively. The regression coefficients (r) were greater than 0.999 , which indicated a high degree of linearity for both drugs (Figures $2 \& 3$ ).

Figure 2: Linearity graph of metronidazole, average area of peks $(\mu \mathrm{V} / \mathrm{sec})$ against concentration $(\mu \mathrm{g} / \mathrm{ml})$

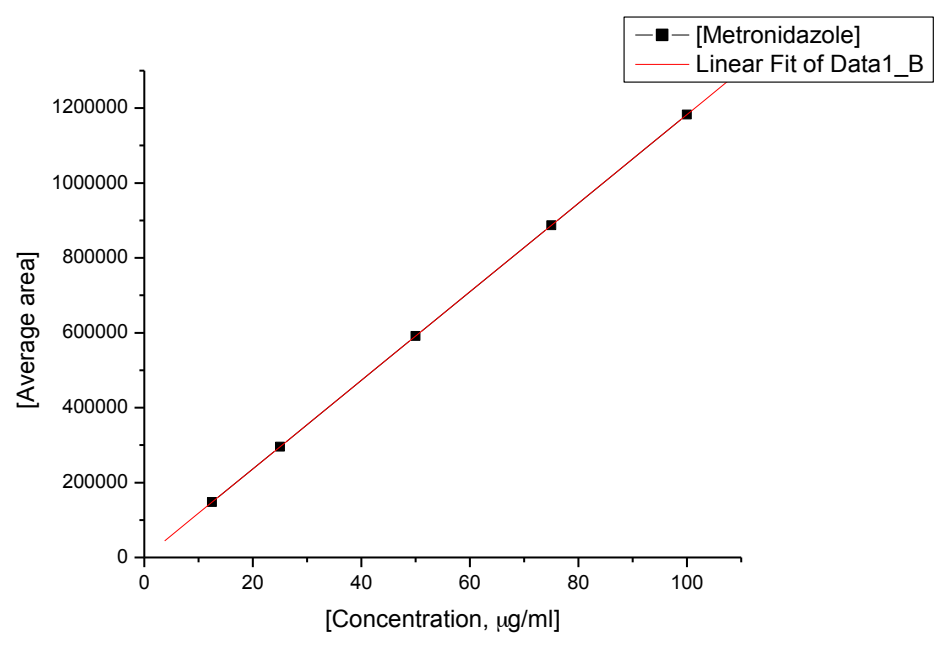

Source: Author 
Fig. 3: Linearity graph of ofloxacin, average area of peaks $(\mu \mathrm{V} / \mathrm{sec})$ against concentration $(\mu \mathrm{g} / \mathrm{ml})$

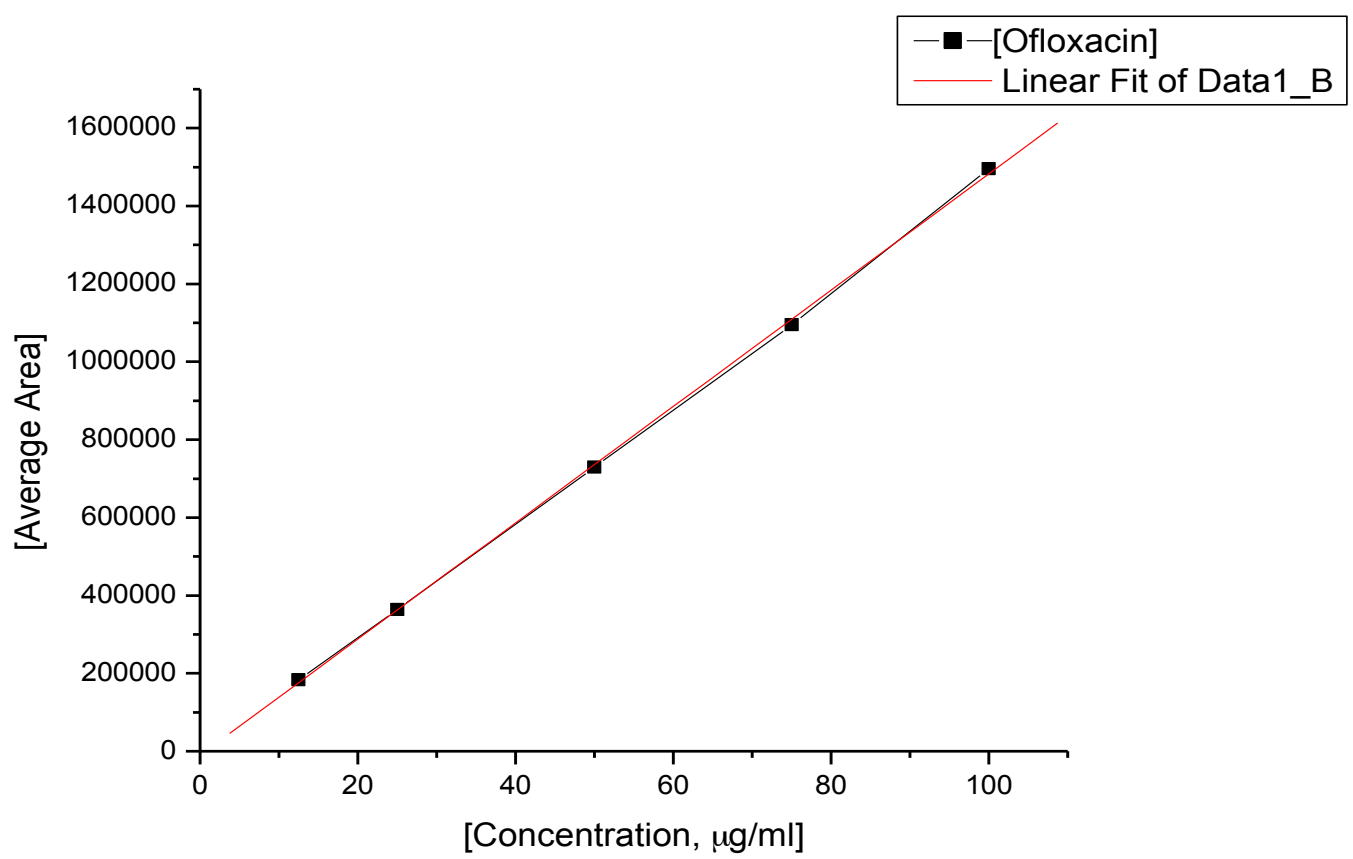

Source: Author

Table 1: Linearity data for Metronidazole and Ofloxacin

\begin{tabular}{|c|c|c|r|r|}
\hline & \multicolumn{2}{|c|}{ Metronidazole } & \multicolumn{2}{c|}{ Ofloxacin } \\
\hline Linearity Level & $\begin{array}{c}\text { Concentration } \\
(\mu \mathrm{g} / \mathrm{ml})\end{array}$ & $\begin{array}{c}\text { Average Area } \\
(\mu \mathrm{V} / \mathrm{sec})\end{array}$ & $\begin{array}{c}\text { Concentration } \\
(\mu \mathrm{g} / \mathrm{ml})\end{array}$ & $\begin{array}{c}\text { Average Area } \\
(\mu \mathrm{V} / \mathrm{sec})\end{array}$ \\
\hline $\mathbf{1}$ & 12.5 & 147627 & 12.5 & 183072 \\
$\mathbf{2}$ & 25.0 & 295865 & 25.0 & 363759 \\
$\mathbf{3}$ & 50.0 & 591336 & 50.0 & 729773 \\
$\mathbf{4}$ & 75.0 & 887012 & 15.0 & 1094660 \\
$\mathbf{5}$ & 100.0 & 1182672 & 100.0 & 1495468 \\
\hline $\mathbf{N}=\mathbf{5}$ & & 0.999 & & 0.999 \\
$\mathbf{r}$ & & \multicolumn{3}{|}{} \\
\hline
\end{tabular}

Source: Author

For determining the limit of detection (LOD) and limit of quantitation (LOQ), the method based on signal to noise ratio (3:1 for LOD and 10:1 for LOQ) was adopted (ICH guidelines (2005)). The limit of detection for MET was $0.125 \mu \mathrm{g} / \mathrm{ml}$ and for OFL $0.250 \mu \mathrm{g} / \mathrm{ml}$, while the limit of quantitation for MET was $0.250 \mu \mathrm{g} / \mathrm{ml}$ and for OFL, $0.300 \mu \mathrm{g} / \mathrm{ml}$.

Intra-daily precision was evaluated by calculating the standard deviation (SD) of six replicate determinations using the standard solutions. The SD values revealed the high precision of the method (values were in the range of 0.77 to 0.98 for both drugs). For inter-daily reproducibility, a series was run, in which the standard drug solutions were analyzed over five consecutive days. The SD values were in the range of 0.98 to 1.90 .

The accuracy of the method was specified by preparing samples of $25 \%, 50 \%, 100 \%, 150 \%$, and $200 \%$ of the target concentration. Each concentration level was injected three times. The results showed perfect recoveries (Table 2). 
Table 2: Results of the analysis for the proposed method

\begin{tabular}{|c|c|c|c|c|c|c|}
\hline \multirow[t]{2}{*}{ Parameters } & \multirow[b]{2}{*}{$\begin{array}{c}\text { Taken } \\
(\mu \mathrm{g} / \mathrm{ml})\end{array}$} & \multicolumn{2}{|c|}{ Metronidazole* } & \multirow[b]{2}{*}{$\begin{array}{l}\text { Taken } \\
(\mu \mathrm{g} / \mathrm{ml})\end{array}$} & \multicolumn{2}{|c|}{ Ofloxacin* } \\
\hline & & $\begin{array}{l}\text { Found } \\
(\mu \mathrm{g} / \mathrm{ml})\end{array}$ & $\begin{array}{c}\text { Recovery } \\
\%\end{array}$ & & $\begin{array}{l}\text { Found } \\
(\mu \mathrm{g} / \mathrm{ml})\end{array}$ & $\begin{array}{c}\text { Recovery } \\
\%\end{array}$ \\
\hline & 12.5 & 12.4 & 99.20 & 12.5 & 12.3 & 102.50 \\
\hline & 25.0 & 25.1 & 100.40 & 25.0 & 24.9 & 99.60 \\
\hline & 50.0 & 50.3 & 100.60 & 50.0 & 50.1 & 100.20 \\
\hline & 75.0 & 75.1 & 100.10 & 75.0 & 74.8 & 99.73 \\
\hline & 100.0 & 99.8 & 99.75 & 100.0 & 99.9 & 99.93 \\
\hline Mean & & & 100.01 & & & 100.40 \\
\hline \pm SD & & & 0.55 & & & 1.20 \\
\hline \pm Relative SD & & & 0.55 & & & 1.19 \\
\hline$\pm \mathbf{S E}$ & & & 0.25 & & & 0.54 \\
\hline
\end{tabular}

\section{Conclusion}

The high performance liquid chromatographic method described in this paper was developed for quantitative control and determination of the contents of MET and OFL. It can be applied in clinical pharmacy, toxicology, and for routine analysis of tablet formulations. The method has high degree of accuracy and precision (less than to $2 \%$ Relative SD) and requires a markedly short performance time (7 min). The parameters for validation of the method (linearity, accuracy, and precision) meet all requirements of the International Council for Harmonization (ICH). One advantage of this method is that it does not use buffers, which are onerous to prepare. The procedure is also simple and easy for implementation.

\section{Acknowledgment}

The present study was realized with the support of Project No. 34/2015 for the Medical Science Council, at the Medical University, Sofia.

\section{References}

Abdulgader, S., Ebraheem, M., \& Elbashir, A. A. (2012). Spectrophotometric Method for the Determination of Ofloxacin and Levofloxacin in Pharmaceutical Formulations. American Academic \& Scholarly Research Journal, 4(2): 1-6.

Attimarad, M. (2010). Rapid RP-HPLC Method for quantitative determination of Lornoxicam in tablets. J Basic and Clinical Pharm. 5: 51- 57.

Bhusari, K. P., \& Chaple, D. R. (2009). Simultaneous Spectrophotometric Estimation of Ofloxacin and Ornidazole in Tablet Dosage Form. Asian J. Res Chem, 2: 60-62.

Bind, B., Lokhande, R., Munigela, N., Kolhal, S., \& Gupta, A. (2015). RP-HPLC Method for the Simultaneous Determination of Metronidazole, Tinidazole, Ornidazole, Secnidazole and Ofloxacin in Bulk and Pharmaceutical Dosage Form, Int. J. Pharm. Sci. Rev. Res., 34(2): 61-67.

Block, J. H., \& Beale, J. M. (2004). Wilson and Gisvold's Textbook of Organic Medicinal and Pharmaceutical Chemistry. 11-th ed. Philadelphia: Lippincott Williams \& Wilkins.

British pharmacopeia (2007). Vol. II, London. The British Pharmacopoeia Commission; 1412-1413.

European Pharmacopoeia (2005). Vol. II, Strasbourge, Directorate for the quality of Medicines of Council of Europe; 21312132 . 
Fairclough, P. D., \& Silk, D. B. A. (2005). Clinical Medicine. In: Kumar P, Clark M. editors. Gastrointestinal disease. $7^{\text {th }}$ ed. Amsterdam: Elsevier; p. 241-359.

Hesham, S. (2005). Spectrofluorimetric, Atomic Absorption Spectrometric and Spectrophotometric Determination of Some Fluoroquinolones. American Journal of Applied science, 2: 719-729.

ICH guidelines (2005). International Conference on Harmonisation of Technical Requirements for Registration of Pharmaceuticals for Human Use, ICH Harmonised Tripartite Guideline, Validation of Analytical Procedures: Text and Methodology Q2(R1), Current Step 4 version, November 2005.

Kasabe, A. J., Shitole, V. V., Waghmare V. V., \& Mohite, V. (2009). Simultaneous Estimation of Metronidazole and Ofloxacin in Combined dosage form by Reverse Phase High Performance Liquid Chromatography Method, Int. J. of ChemTech Res., 1(4): 1244-1250.

Khandagle, K. S., Gandhi, S. V., Deshpande, P. B., \& Gaikwad, N. V. (2011). Simple and Sensitive RP HPLC method for Simultaneous estimation of Cefixime and Ofloxacin in combined dosage form. Int. J. Pharmacy and Pharmaceutical Sciences, 3: $46-48$

Khadabadi, S. S., \& Devkar, M. G. (2013). A validated RP-HPLC method for simultaneous estimation of metronidazole and ciprofloxacin hydrochloride in pharmaceutical dosage form. Int J Pharm Sci Res; 4: 4736-4740.

Kotaiah, M. R., Shaikh, H. R., Rao, Y. N., Venkateswarlu, Y., \& Konda, R. K. (2011). Simultaneous estimation of ofloxacin and tinidazole in tablet dosage form by RP-HPLC. Res. J. Pharm. Bio. Chemical Sciences, 2: 53-57.

Leea, H. B., Pearta, T. E., \& Svobodab, M. L. (2007). Determination of Ofloxacin, Norfloxacin and Ciprofloxacin in Sewage by Selective Solid Phase Extraction, Liquid Chromatography with Fluorescence Detection and Liquid ChromatographyTandem Mass Spectrometry. Chromatogr. A, 1139: 45-52.

Mahrouse, M., \& Elkady, E. (2011). Validated spectophotometric methods for the simultaneous determination of ciprofloxacin hydrochloride and metronidazole in tablets. Chem Pharm Bull, 59: 1485-1493.

Mahrouse, M. (2012). Development and validation of a UV spectrophotometric method for the simultaneous determination of ciprofloxacin hydrochloride and metronidazole in binary mixture. J Chem Pharm Res, 4: 4710-4715.

Miniyar, P. B., Milani, A. I., Dhange, A. A., Gawande, V. T., \& Kashid, A. M. (2012). Development and Validation of RPHPLC Method for Simultaneous Determination of Ofloxacin and Ornidazole in Infusion. American J. of PharmTech Research, 2(5): 382-390.

Monk, J. P., \& Campoli-Richards, D. M. (1987, Apr.). Ofloxacin. A review of its antibacterial activity, pharmacokinetic properties and therapeutic use. Drugs, 33(4): 346-391.

Narayana, L. K., Manohara, Y. N., \& Appala, R. S. (2006). Development and validation of RP-HPLC method for the estimation of Nitazoxanide \& Ofloxacin in combined tablet dosage form. Indian Drugs, 43: 503-506.

Natesh, G. (2013). A new analytical method development and validation for estimation of ciprofloxacin and metronidazole by iso absorption method by using UV spectrophotometer. J Chem Biol Phys Sci. 3: 1663-70.

Patel, S. (2011). Development and validation of HPLC Method for simultaneous estimation of Ofloxacin and Metronidazole from pharmaceutical formulation, Int J Pharm Front Res, 1(2): 68-74.

Patel, A., Shah, N., \& Patel, N. (2009). Simultaneous estimation of metronidazole and ciprofloxacin by RP-HPLC method in bulk drug and suspension. Int J Chem Sci, 7: 2115-2121.

Piponski, M., Bakovska, T., Naumoska, M., Rusevska, T., Serafimovska, G., \& Andonovska, H. (2015). Preliminary investigation of the possibility for implementation of modified pharmacopoeial HPLC methods for quality control of metronidazole and ciprofloxacin in medicinal products used in veterinary medicine. Maced Vet Rev; 38: 31-42.

Ramzia, I., Asma, A., Ehab, E., Maha, M., \& Asma, M. (2015). Stability indicating HPLC method for the simultaneous determination of ciprofloxacin hydrochloride and metronidazole in the presence of ciprofloxacin acid degradation product. Asian J Biochem Pharm Res; 1: 5-17.

Rege, P. V., Sathe, P. A., Salvi, V. S., \& Shotri, C. K. (2011). Simultaneous Spectrophotometric Estimation of Ofloxacin and Ornidazole from Combined Tablet Dosage form. Int. J. Pharma World Research, 2: 1-24.

Shinde, S. R., Bhoir, I. S., Pawar, N. S., Yadav, B. S., \& Bhagwat, M. A. (2010). Simultaneous Estimation of Satranidazole and Ofloxacin in Tablet Dosage form by High Performance Liquid Chromatography. E. J. Chem, 7: 198-202.

Shivkumar, C. V., Gunturu, C., \& Indrakanti, M. (2011). Second and Third Order Derivative Spectrophotometric Estimation of Ofloxacin in Bulk and Pharmaceutical Dosage Form. Inter. J. Pharmacy and Technology, 3(3): 3083-3091.

Tuerk, J., Reinders M., Dreyer D., Kiffmeyer, T. K., Schmidt, K. G., \& Kuss, H. M. (2006). Analysis of Antibiotics in Urine and Wipe Samples from Environmental and Biological Monitoring-Comparison of HPLC with UV, single MS and Tandem MS Detection. J. Chromatogr. B, 831, 72-80.

Tuncel, M., \& Atkosar, Z. (1992). Determination of Ofloxacin in Tablet by Potentiometry and Conductometry. Pharmazie, 47: 642-643.

United State Pharmacopoeia (2005). Vol. II, Rockville, United States Pharmacopoeial convention; 1413-1415.

Vinay, K. B., Revanasiddappa, H. D., Divya, M. R., \& Rajendraprasad, N. (2009). Spectrophotometric determination of ofloxacin in pharmaceuticals and human urine. Ecl. Quím. São Paulo, 34(4): 65 - 77. 